\title{
Harmonizing Budgeting and Accounting: The Case of Italy
}

\author{
Adriana Bruno \\ Management of Public Administration, University of Salerno, Salerno, Italy \\ Email: abruno@unisa.it
}

Received November 6, 2013; revised December 23, 2013; accepted December 31, 2013

Copyright (C) 2014 Adriana Bruno. This is an open access article distributed under the Creative Commons Attribution License, which permits unrestricted use, distribution, and reproduction in any medium, provided the original work is properly cited. In accordance of the Creative Commons Attribution License all Copyrights (C) 2014 are reserved for SCIRP and the owner of the intellectual property Adriana Bruno. All Copyright (C) 2014 are guarded by law and by SCIRP as a guardian.

\begin{abstract}
Many reforms have been undertaken in recent years; indeed, scholars have concentrated their attention on accounting techniques, financial management, and the potential for adding tools to support managerial reform agendas [1-3]. This paper extends prior research by focusing on the manner of diffusion ongoing reform process, through the adoption of the new version of Financial Management Reform process model [3]. The objective of this research is to investigate how a new accounting system has been introduced in the public sector in a processual and outcome-oriented analysis [4]. The study setting for this research is the Italian government, specifically the intermediate or regional level government, Campania Region, where a trial period is underway. The objective is to discover what obstacles and difficulties might exist when implementing a harmonized accounting and budgeting system while moving toward an accrual accounting system. The study reveals the main paradox in the implementation of the reform. This kind of study could add fresh knowledge to the literature and highlight common problems encountered when implementing accounting reforms. Additionally it could help set a standard to assist public entities in developing and implementing accounting guidelines.
\end{abstract}

\section{KEYWORDS}

\section{Harmonization; Regional Government; Accounting and Budgeting Reform}

\section{Introduction}

In recent years, the role and function of the state in contemporary societies has expanded to respond to the financial crisis and economic recession. Different accounting systems are still spread in the countries. The recent financial crisis has highlighted the need for reform in public sector accounting; indeed, OECD countries need to develop a process of convergence in accounting practices, the harmonization process, which is mostly addressed to the comparability of financial reporting across countries. This process is aimed to better satisfy information needs of a different kind of stakeholder. Moreover, this could be the most effective and cost efficient strategies for governments to "globally" recognize crisis and as a consequence to "globally" implement political solutions. Thus, there is a strong need for international harmonization to achieve a standardized accounting language because it will also support a globalized implementation of public policy [6].

Harmonization is a process used to build comparable accounting summary documents for the whole public administration $[7,8]$. This process is complex because it requires the homogeneity of rules, models, glossaries and procedures. Accounting is the process of identifying, measuring, and communicating economic information so that users can use that information to make informed judgments and decisions. In literature it is possible to find ex-post studies about harmonization [8,9]. For example, one study defines the difference between de jure and de facto harmonization. De jure, harmonization is a process driven by a regulator, typically the legislature or another entity (such as the standard setter). De facto harmonization is spontaneous behavior accountants allowing to achieve increasing levels of harmony [8]. International studies also detail the grade of harmony achieved after a harmonization reform [9]. However, as highlighted by a large set of research in previous decades, it is difficult to make a clear distinction between a de facto harmonization (spontaneous and more advisable) or de jure harmonization, which comes as a consequence of 
legal requirements. Thus, after decades of discussions, scholars have not achieved a common view on this topic. However, governments worldwide are making some efforts to adopt similar accounting systems. This study intends to analyze the current reforms within public accounting in Italy (still ongoing). The Italian effort is a harmonization reform which is moving the government towards to an accrual accounting system [10]. To this end, the paper will unfold as follows: Section 2 is dedicated to a brief review of literature on harmonization and public sector accounting reform; Section 3 describes theoretical approaches adopted in this study, the contingency approach; Section 4 illustrates the research objective and the research questions; Section 5 presents accounting reforms in Italy; Section 6 draws conclusions and shows outlines possibilities for future research.

\section{Prior Research on Accounting Reform: A Literature Review}

Since the introduction of New Public Management paradigm, which is tasked with improving the efficiency and effectiveness of public action, the entire accountability system is experiencing a widespread reform. Many governments have undertaken reforms in recent years. One of the key elements within New Public Financial Management is public sector accounting reform, which focuses on harmonization of accounting and financial reporting models. Indeed, the International Public Sector Accounting Standards Board (IPSASB) has issued accounting standards to Public Administrations, inspired by International Financial Reporting Standards (IAS/IFRS) [10,11].

Many countries are carrying out reforms to modernize their accounting systems by introducing accrual accounting [12]. The countries that have adopted accrual accounting have generally been at the forefront of public management reforms [13]. In 2003, many authors provided an overview of public sector accounting reform, studying the relationship between accounting practice and social context; it is possible to find studies about public sector accounting reform that have been conducted adopting the contingency framework. They studied the transition from cash to accrual accounting in the central government in Germany, Finland, France, Italy, Netherlands, Spain, Sweden, Switzerland and the United Kingdom [13]. The contingency theory is also used to examine the contingent variable (external and internal factors), which can lead the need for change, such as the organization's environment, structure and technology [14, 15]. Recently, a report by Ernest and Young, which was prepared for Eurostat in 2012, identified the state of art accounting reforms in central and local government in European countries [16].

Scholars have studied public sector accounting reforms in many countries and found similar difficulties in detecting effective systems in use. Some researchers have shifted their attention to implementation issues. It also demonstrates the importance of instituting a trial period which is a factor recognized by public accounting scholars [17-19]. They have investigated the structural weaknesses of the reform projects. They are looking in particular at the role played by organizational conditions within public administrations during the implementation of an accrual accounting system. These studies reveal the failure of an excessive confidence in universal and standardized solutions. However, it is still difficult to explain what factors lead a system to adopt a harmonization process, or moves them toward accrual accounting. It is also difficult to define the main obstacles in achieving this result.

This research analyzes, the Italian case, considering the last study that adopted the process- and outcomeoriented analysis based on regional government by Lüder, "Accrual Accounting and Budgeting in Government-A History of the Hessian New Administrative Management (NVS) Project," which was presented to the 14th Biennial Cigar Conference in Birmingham. This paper illustrates the last version of the Financial Management Reform Process Model where the author compares the case of the State of New South Wales, in Australia [2,21] and the case of Hessen. Adopting the new model and comparing Hessen and NSW, Lüder shows these scientifically relevant findings, summarized in Table 1.

Since 1980, Australia and New Zealand have undergone a successful public sector accounting reform. However, a recent study by Parker and Christensen describes some difficulties related inertia and resistance to change among the public sector in the State of New South Wales. The research objective in that study was to understand the public sector accounting and financial management changes in NSW. This study adopted a historical approach using the neo-institutional theory. The paper clearly shows the dominant influences of the consultants, the competitive situation between the public sector accountants and economists, and the Premier's actions [5: p. 261; 20,21].

Germany began an accounting reform in central government in 2006, called New Administrative Management Project. The project was abandoned in July 2010 by the Bundestag (the Parliament) for lack of funds. It was later reshaped with reduced financial resources. In its experiments and pilot projects, the State of Hessen gained considerable experience in reforming budgeting and accounting, however many difficulties and constraints remained [3,22].

\section{Research Design: The Processual Approach to Study an Accounting Reform}

This study could be defined as an "interpretational analy- 
Table 1. Main scientifically relevant findings by Lüder 2013.

\begin{tabular}{|c|c|c|}
\hline Main results & Australia NSW & Germany Hessen \\
\hline Stimuli/intentions of the reform & Modernize the government & Modernize the government \\
\hline Implementation strategy and speed & $\begin{array}{l}\text { Immediate progress; top-down } \\
\text { and "bombing" strategy }\end{array}$ & $\begin{array}{l}\text { Authoritarian; top-down but more rational } \\
\text { based on convincing and training }\end{array}$ \\
\hline $\begin{array}{l}\text { Influence of epistemic communities } \\
\text { and private consultant }\end{array}$ & Strong consultant-dependency & $\begin{array}{l}\text { Weak influence because there are } \\
\text { different expertise }\end{array}$ \\
\hline Implementation barriers & $\begin{array}{l}\text { Flawed asset accounting records } \\
\text { and inadequate public sector } \\
\text { accounting expertise }\end{array}$ & $\begin{array}{c}\text { Some problems have been overcome in } \\
\text { different way during the } \\
\text { implementation }\end{array}$ \\
\hline Impact of the reform & It was mostly cosmetic & $\begin{array}{l}\text { The period is still short } \\
\text { for a final judgment }\end{array}$ \\
\hline
\end{tabular}

Source: Author's elaboration from Accrual Accounting and Budgeting in Government-A History of the Hessian "New Administrative Management (NVS)” Project (Lüder, 2013).

sis” based on a new version of the Financial Management Reform Process Model. The objective of this research is to explain how a process of harmonization reform emerges in a country, what forces are involved in this process and the way in which these forces are able to influence the outcome. This is a processual research: it outlines "how things change over the time." Indeed, processual research looks at processes and patterns in a societal context.

Prior literature adopted the contingency theory in many cases. In this study this theoretical framework was very useful in building a strong macro-level study. The contingency model will be used in this research as a lens for contextual features, which are, the main stimuli that triggered the reform, the key player in the reform process and the implementation strategy. The contingency theory is also used to examine the contingent variable, (external and internal factors) which can lead the need for change. The contingent variable may include the organization's environment, structure and technology. External factors can create uncertainty, i.e., market pressure, new technology and political issues. Internal factors, on the other hand, are almost related to factor potentially affecting organizational structure, budgetary control and performance measurement of the organization [23].

The "contingency model" and "reform process model" are "skeleton models" or static models [3: p. 9; 24: p. 81]. This model identify relevant contextual factors at highabstraction levels well as key players in a reform of the budgeting and accounting system; more over these model explain the significance of these factors in reform and thus provide the point of departure for an analysis of budgeting and accounting innovations. However, as described by Laughlin, it is required "middle-range thinking”; this thinking is supplemented by empirical details: “... empirical detail is of vital importance”. Distinctive details for a particular reform process are provided by the case study of the trial project reform in Campania region. It contributes to our knowledge of budgeting and accounting reform and provides the ability to perform more realistic modeling.

The analysis process can be divided into three stages. It follows the steps of the section "process" underlined in the model: Initiation: this is the initial step during which the reform is shaped; a conceptual design is drawn by political reform promoters; Implementation: this is the second step, the reform effort begins; New system in operation: this is the final stage where it is possible to analyze the impact of the reform on public action, the accountability system and government decision-making. In the first phase of the study the author conducted a documentary analysis. The aim was to collect laws and internal rules related to the Italian trial harmonization process in the Campania region. It was a contextual analysis based on relevant publications, reports in a web site dedicated to the trial (arconet), and internal documents. Thus, information on the "conceptual design" could be obtained from written material.

During the second phase of this analysis, the study author sent a questionnaire to Campania-region employees responsible for the trial, including the head of the financial department and accountants involved among others in the process. Moreover, the study author conducted semi-structured interviews. These interviews were based on organized guides and included 20 face-to-face interviews, which lasting one hour each. The interviews were with individuals involved in different types of jobs during the duration of the accounting harmonization trial. The case-study analysis is appropriate in a study when the focus is ongoing phenomena within real operational contexts, which in this case is an in-depth case study the Campania region [25]. The interview method is appro- 
priate for exploratory studies of complex issues, especially if they are supplemented by document analyses". Following the interview analysis, additional personal talks were held with several interviewees. These talks aimed at clarifying and amending facts and opinions where necessary. Theoretically, the study could have been based either exclusively on a written survey, exclusively on document analysis, or a combination of both. However, the study author did not consider these empirical research methods adequate or preferable to the combination used, which was a written survey, oral interviews and document analysis. Thus, the data collected includes, observations, interviews, informal conversations and documents. In a final stage, the data collected could be used to triangulate information. The study author will carry out the final stage during the next few months because the Italian accounting harmonization trial is still underway; so it is not possible to evaluate the final impact of the reform.

\section{Research Objective and Research Questions}

Process-oriented studies based on a modified reform process model were also submitted by Caba-Perez et al., they extend the model by specifying and including process-variables However, it does not include an empirical investigation of these variables [26]. Instead, the focus of the study is on contextual factors, such as reform stimuli, the significance of the legal setting for reform implementation, the role of political and administrative key players in project initiation and implementation and, the impact of the reform on government management. The research questions are therefore: What are the reasons for the reform? What were the underlying objectives and expectations? Who initiated the project and who influenced it? How was the project implemented and what problems emerged during implementation? Which experience was gained from implementation? This study contributes to the understanding of the complexity of factor involved in a Public Sector reform, as they relate to technical issues. The Italian case is particularly interesting since Italy is at a crucial point in its initial stage of harmonization reform. The aim of this research is to discuss process in context with regional authorities. This will offer unique evidence because the intermediate level of government is studied less frequently than local government and national government, in national [27] and international literature [28].

\section{The Process of Reform in Italy: Findings in a Case Study}

The findings of this research are presented considering each module depicted in Figure 1: actors-process-context. Following the Financial Management Reform process model, (Figure 1), the Political Reform promoters in the actual Italian reform are the Parliament and the

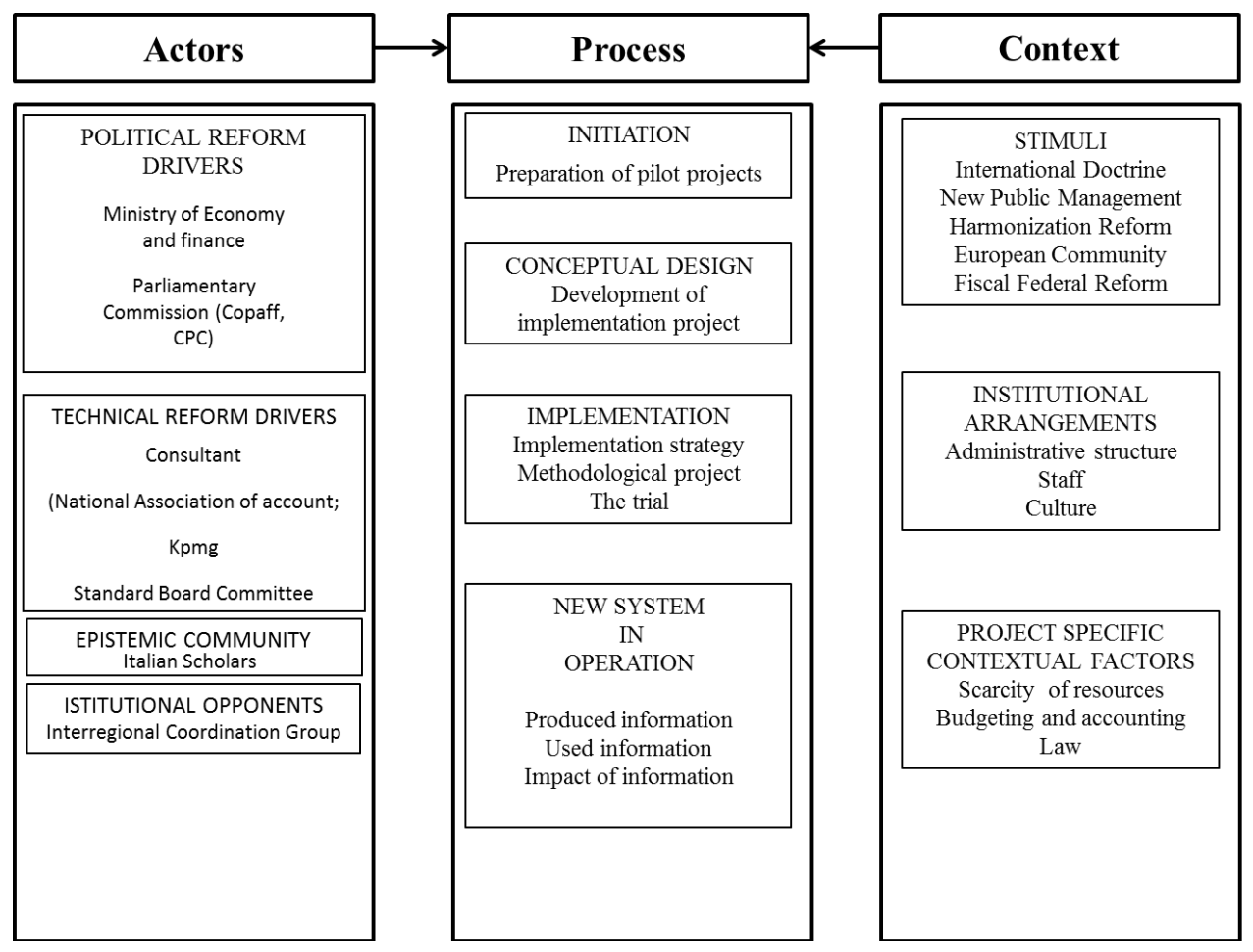

Figure 1. New financial management reform process model. Source: Author's elaboration from Accrual Accounting and Budgeting in Government-A History of the Hessian “New Administrative Management (NVS)” Project (Lüder, 2013). 
Ministry of Economy and Finance. Italy is a civil-law country. Its institutional system is typical for continental Europe. The government is characterized by the constitution and a separation of powers between the legislature and the executive branches of government. The Parliament is the political authority, which puts forward proposals and the Minister of the Economy and Finance, as coordinator of public finance accounts, receives, examines and evaluates the proposal.

The State General Accounting Department, (Ragioneria Generale dello Stato) which is part of the Ministry of Economy and Finance, is the central control body that supports this reform process, defined as Technical Reform Drivers. Generally, it aims to ensure the uniform interpretation and application of accounting rules. It also controls the financial administration of public institutions through inspection activities. However, the Department's functions have recently been extended in order to carry out activities to support the identification of financial management standards for the entire Public Administration system to share and adopt. This Department has a specific work group, which is dedicated to this reform. This work group meets every Tuesday to oversee the trial in regional and local government.

Moreover, other Technical Committees influence the reform process. The role of the Committees can be summarized as follows: to undertake surveys, to provide additional information to policy makers; and to conduct advisory work in intergovernmental relations. The most important Committee in the Parliament involved in this reform is the Committee for Fiscal Federalism Reform (Commissione Parlamentare per l'attuazione del Federalismo Fiscale).

As Technical Reform Driver, the National Association of Accounts is the official standard setter for the reform. Moreover, members of these associations are consulted and are thereby directly involved in shaping the system. In particular, they give interpretations during the implementation process. The most important actor in this field is the Standard Board Committee, (Comitato per I principi contabili) which works with the Minister of Economy and Finance; there are Italian professors of public accounting in these Committees. The respondents declared that this "informal group" exerted a considerable influence because after request of comments "about the accrualthey formulate guidelines during the "initiation phase." and during the "implementation phase; they participate to the trial sending guidelines. So the epistemic community exert significant influence on the reform.

Furthermore, in this reform the Conference of the State Regions plays also an important role in the administrative systems, particularly in recognizing the specific interests of local and regional governments. More specifically, an Interregional Coordination Group it is involved in all government decision-making affecting regional and inter-regional interests as Institutional Opponents. The Institutional opponents are those able to influence the reform. These can be external or internal actors, and they could have a "positive influence" as reform drivers or a "negative influence” as reform opponents (inhibitors). As external actor, the Interregional Coordination Group requested that the Ministry postpone the trial for one year. The Ministry accepted the request. As an internal actor, some employees request to exclude the region for accrual accounting implementation because it was considered not useful for the core activity of the regional government. However, this request was rejected.

Promoters play also a significant role in a reform process. These can be internal or external. External promoters are predominant in the Campania region. The professional promoters involved in the trial is a KPMG partner; he was nominated (Regional Decree n. 227 of 10th of October 2012) as official consultant for the "centralized" management of the health sector system, implementing the integrated accrual accounting system. The employees and the KPMG consultant started to analyze the financial transactions for the implementation of the new system. In particular, during the observation period, KPMG studied the health-management cycle in terms of the principles of accrual accounting. The interview revealed that the KPMG partner played the leading role in the health care reform process due to their advantage and expertise.

If we look at the Stimuli and the intentions of the reform, in Campania region, the budgeting and accounting reform was mainly related to the harmonization, which comes from fiscal federal reform. The implementation strategy was a bottom-up process, a trial of three years, which involves almost 150 entities. During the trial, entities share implementation experiences, using FAQs. They also organize a weekly phone conference.

The Implementation barriers are obstacles that may delay the reform, impede it, require detours and in an extreme case even prevent implementation. These obstacles are not controllable in the short term. In the Campania region these barriers were related, for example, to the "asset records" (depreciation and evaluation) caused by inadequate accounting expertise. There is also scarcity of resources to modernize the ICT system. These problems had to be resolved in course of the implementation. Respondents also said that some of these issues were shared by other regions in the trial and they were overcome in different ways and at higher or lower cost, depending on the point of departure. For example, in Lombardia region, the "resources variable" is not a serious impediment to the reform. The respondents declared that the reform was imposed to satisfy a harmonization need and it was not a voluntary decision. The decision to 
Table 2. Main contribution: A first comparative overview.

\begin{tabular}{|c|c|c|c|}
\hline Main results & Australia NSW & Germany Hessen & Italy Campania \\
\hline Stimuli/intentions of the reform & Modernize the government & Modernize the government & Harmonization \\
\hline $\begin{array}{l}\text { Implementation } \\
\text { strategy and speed }\end{array}$ & $\begin{array}{l}\text { Immediate progress; top-down and } \\
\text { "bombing" strategy }\end{array}$ & $\begin{array}{l}\text { Authoritarian; top-down but more } \\
\text { rational based on convincing and } \\
\text { training }\end{array}$ & $\begin{array}{l}\text { Bottom up process: a trial period } \\
\text { based on the shared experiences. }\end{array}$ \\
\hline $\begin{array}{c}\text { Influence of epistemic } \\
\text { communities and private } \\
\text { consultant }\end{array}$ & Strong consultant-dependency & $\begin{array}{l}\text { Weak influence because there are } \\
\text { different expertise }\end{array}$ & $\begin{array}{l}\text { Strong influence of Epistemic } \\
\text { Community and consultant } \\
\text { (KPMG) }\end{array}$ \\
\hline Implementation barriers & $\begin{array}{l}\text { Flawed asset accounting } \\
\text { records and inadequate public } \\
\text { sector accounting expertise }\end{array}$ & $\begin{array}{l}\text { Some problems have been overcome in } \\
\text { different way during the implementation }\end{array}$ & $\begin{array}{l}\text { There is no clarity in the } \\
\text { guidelines and the standards are } \\
\text { translate form private sector } \\
\text { without any type of adjustment }\end{array}$ \\
\hline Impact of the reform & It was mostly cosmetic & $\begin{array}{l}\text { The period is still short for } \\
\text { a final judgment }\end{array}$ & $\begin{array}{l}\text { The period is still short } \\
\text { for a final judgment }\end{array}$ \\
\hline
\end{tabular}

Source: Author's elaboration from Accrual Accounting and Budgeting in Government-A History of the Hessian "New Administrative Management (NVS)" Project (Lüder, 2013).

implement accrual accounting was strongly challenged by regions, because it is not considered for the regional management of public resources. At a regional level, the cultural barrier was stronger than in local government. Assessing the final impact of the reform in the Campania Region is not possible at this point, because the trial is still ongoing.

\section{Conclusions, Limitations and Further Research}

In terms of contribution, the Campania study [29] reveals some difference and similarities from the Lüder study (the NSW and Hessen investigation), summarized in Table 2.

Summarizing, the answers to the research questions are: What are the reasons for the reform? What were the underlying objectives and expectations? The main goal of the Italian reform is the internal harmonization which seems to be the solution to the current heterogeneity caused by the adoption of different criteria between central, regional and local administration [30-32]. Who initiated the project and who influenced it? The main promoter of the reform is the State General Accounting Department which is part of the Ministry of Economy and Finance. The Epistemic Community and the Private Consultant are influencing it. How was the project implemented and what problems emerged during implementation? Which experience was gained from implementation? There is an inadequate accounting expertise, scarcity of resources to modernize the ICT system, and a "cultural barrier" which is perceived stronger in regional government. The results of a single, in-depth case study cannot be generalized, not even in the form of hypotheses. However, generalizations are feasible if a larger number of comparable single case studies are available. An idea for a further research is to replicate the study in
Germany with the collaboration of professor Lüder as well as in Italy, catching the impact of the reform in the new system in operation. It would focus on accountability and decision-making, adopting a comparative study, a technique encouraged by researchers [33]. The choice of these two countries is also motivated by this aspect: the main obstacles and difficulties already experienced and overcome in the Germany reform are a good point of analysis for the Italian reform.

\section{Acknowledgements}

The author is grateful to Professor Klaus Lüder met in 14th Cigar Conference in Birmingham. He has helped to improve and develop this paper.

\section{REFERENCES}

[1] C. Hood, “The 'New Public Management' in the 1980s: Variations on a Theme," Accounting, Organizations and Society, Vol. 20, No. 2-3, 1995, pp. 93-109. http://dx.doi.org/10.1016/0361-3682(93)E0001-W

[2] M. Christensen, "Accrual Accounting in the Public Sector: The Case of the New South Wales Government," Accounting History, Vol. 7, No. 2, 2002, pp. 93-124. http://dx.doi.org/10.1177/103237320200700205

[3] K. Lüder, "Accrual Accounting and Budgeting in Government-A History of the Hessian 'New Administrative Management (NVS)' Project," Paper Presented to the 14th Biennial CIGAR Conference, Birmigham, 2013.

[4] A. Pettigrew, "What Is a Processual Analysis," Scandinavian Journal of Management, Vol. 13, No. 4, 1997, pp. 337-348. http://dx.doi.org/10.1016/S0956-5221(97)00020-1

[5] M. Christensen and L. Parker, "Using Ideas to Advances Professions: Public Sector Accrual Accounting," Financial Accountability and Mangement, Vol. 26, No. 3, 2010, pp. 246-264. 
[6] European Commission, Report from the Commission to the Council and the European Parliament, towards Implementing Harmonised Public Sector Accounting Standards in Member States, Brussels, 2013.

[7] L. Cañibano and A. Mora, "Evaluating the Statistical Significance of 'de Facto' Accounting Harmonization: A Study of European Global Players,” European Accounting Review, Vol. 9, No. 3, 2000, pp. 349-370. http://dx.doi.org/10.1080/09638180020017113

[8] R. Di Pietra, "Ragioneria Internazionale e 'Armonia' Contabile,” Padova, Cedam, 2000.

[9] L. Van Der Tas, B. Raffournier, A Haller and P. Walter, "Measuring International Harmonization and Standardization: A Comment," Abacus, Vol. 28, No. 2, 1992, pp. 211-216. http://dx.doi.org/10.1111/j.1467-6281.1992.tb00281.x

[10] B. Benito, I. Brusca and V. Montesinos, “The Harmonization of Government Financial Information Systems: The Role of the IPSASs," International Review of Administrative Sciences, Vol. 73, No. 2, 2007, pp. 293-317. http://dx.doi.org/10.1177/0020852307078424

[11] J. Christiaens and B. Reyniers, "Impact of IPSAS on Reforming Governmental Financial Information Systems: A Comparative Study,” Working paper, University of Gent, 2009, pp. 1-17.

[12] J. Chan, "Government Accounting: An Assessment of Theory, Purpose and Standards," Public, Money \& Mangement, Vol. 23, No. 1, 2003, pp. 13-20.

[13] K. Lüder and R. Jones, "Reforming Governmental Accounting and Budgeting in Europe,” Fachverlag Moderne Wirtschaft, Frankfurt, 2003.

[14] J. Innes and F. Mitchell, "The Process of Change in Management: Some Field Study Evidence,” Management Accounting Research, Vol. 1, No. 1, 1990, pp. 3-19. http://dx.doi.org/10.1016/S1044-5005(90)70042-X

[15] D. Otley, "The Contingency Theory of Management Accounting: Achievement and Prognosis,” Accounting, Organizations and Society, Vol. 5, No. 4, 1980, pp. 413-428. http://dx.doi.org/10.1016/0361-3682(80)90040-9

[16] Ernst and Young, "Overview and Comparison of Public Accounting and Auditing Practices in the 27 EU Member States Prepared for Eurostat,” 2012.

[17] H. J. Ter Bogt and G. J van Helden, “Accounting Change in Dutch Government: Exploring the Gap between Expectations and Realizations," Management Accounting Research, Vol. 11, No. 2, 2000, pp. 263-279. http://dx.doi.org/10.1006/mare.2000.0132

[18] A. Jackson and I. Lapsley, "The Diffusion of Accounting Practices in the New 'Managerial' Public Sector," The International Journal of Public Sector Management, Vol. 15, No. 5, 2003, pp. 359-372.

http://dx.doi.org/10.1108/09513550310489304

[19] I. Lapsley and E. Wright, "The Diffusion of Management Accounting Innovations," Management Accounting Research, Vol. 15, No. 3, 2004, pp. 355-374. http://dx.doi.org/10.1006/mare.2002.0197
[20] M. Christensen and L. Parker, "Using Ideas to Advances Professions: Public Sector Accrual Accounting," Financial Accountability and Mangement, Vol. 26, No. 3, 2010, pp. 246-264.

[21] W. Funnell and K. Cooper, "Public Sector Accounting and Accountabilty in Australia," University of New South Wales Press, Sydney, 1998.

[22] R. Jones and K. Lüder, “The Federal Government of Germany's Circumspection Concerning Accrual Budgeting and Accounting," Public Money \& Management, Vol. 31, No. 4, 2011, pp. 265-270. http://dx.doi.org/10.1006/mare.2002.0197

[23] T. Haldma and K. Lääts, "Contingencies Influencing the Management Accounting Practices of Estonian Manufacturing Companies,” Management Accounting Research, Vol. 13, No. 4, 2002, pp. 379-400. http://dx.doi.org/10.1006/mare.2002.0197

[24] R. Laughlin, "Debate: Accrual Accounting: Information for Accountability or Decision Usefulness?” Public Money \& Management, Vol. 32, No. 1, 2012, pp. 45-46. http://dx.doi.org/10.1080/09540962.2012.643056

[25] R. Yin, "Case Study Research Design and Methods," Sage Ltd, London, 2009.

[26] C. Caba-Pèrez, A. M. Lopez-Hernandez and D. OrtizRodriguez, "Governmental Financial Informations Reforms and Changes in the Political System: The Argentina, Chile and Paraguay Experience,” Public Administration, Vol. 29, No. 5, 2009, pp. 429-440.

[27] E. Caperchione, “Tendenze in Atto nel Rinnovamento del Sistema Informativo-Contabile delle Regioni,” In: F. Pezzani, Ed., A cura di Ripensare il Ruolo e la Governance delle Regioni, Egea, Milano, 2008, pp. 7-22.

[28] J. Broadbent and J. Guthrie, "Public Sector to Public Services: 20 Years of 'Contextual' Accounting Research," Accounting, Auditing \& Accountability Journal, Vol. 21, No. 2, 2008, pp. 129-169. http://dx.doi.org/10.1108/09513570810854383

[29] A. Bruno, "Lo State dell'arte della Sperimentazione in Regione Campania,” Finanza Locale, No. 5-6, 2013, pp. 43-51.

[30] R. Jannelli and C. Tesone, "The Accounting Harmonization Process: Italian Public Principles and International Accounting Standards. Is It a Cultural Choice?” Open Journal of Accounting, Vol. 2, No. 4, 2013, pp. 115-121. http://dx.doi.org/10.4236/ojacct.2013.24017

[31] R. Mussari, "Brevi Considerazioni sui Mutamenti in atto nei Sistemi si Contabilità Pubblica,” Azienda Pubblica, Vol. 25, No. 1, 2012, pp. 11-21.

[32] P. Ricci, "Il Potenziale Impatto delle Nuove Disposizioni Contabili sui Comportamenti Aziendali e sul Sistema Economico,” Azienda Pubblica, Vol. 25, No. 1, 2012, pp. 41-52.

[33] E. Caperchione and I. Lapsley, "Making Comparisons in Government Accounting,” Financial Accountability \& Management, Vol. 27, No. 2, 2011, pp. 103-106. http://dx.doi.org/10.1111/j.1468-0408.2011.00518.x 